\title{
PENGARUH DISIPLIN KERJA, GAYA KEPEMIMPINAN, DAN MOTIVASI TERHADAP KINERJA KARYAWAN PT. BANK PEMBANGUNANDAERAH KALIMANTAN TIMUR DAN KALIMANTAN UTARA(BPD KALTIM KALTARA) CABANG BALIKPAPAN
}

\author{
Tamzil Yusuf, Rahma \\ Universitas Balikpapan
}

\begin{abstract}
Abstrak
Dunia perbankan mengalami perkembangan yang sangat pesat, kenyataan seperti ini tidak dapat dipungkiri lagi sehingga setiap bank dituntut untuk menggunakan berbagai cara dalam menarik minat masyarakat. Sehingga organisasi perlu memfokuskan pada kinerja pelayanan untuk memuaskan nasabahnya. Tujuan penelitian untuk mengetahui Disiplin Kerja, Gaya Kepemimpinan, Dan Motivasi secara bersama-sama mempunyai pengaruh Terhadap Kinerja Karyawan PT Bank Pembangunan Daerah Kalimantan Timur dan Kalimantan Utara (BPD Kaltim Kaltara) Cabang Balikpapan, jumlah populasi 136 dan sampel yang digunakan 50\% sebanyak 68 orang dan alat analisis Regresi linear berganda. Hasil persamaan regresi berganda secara simultan terbukti bahwa variabel Disiplin, Gaya Kepemimpinan, dan Motivasi berpengaruh terhadap Kinerja karyawan Bank Kaltimtara Cabang Balikpapan. Hasil secara parsial dengan pengujian signifikansi 5\% dengan dua sisi diperoleh diperoleh nilai koefisien korelasi parsialnya (r) lebih besar dari hasil pengujian secara parsial pada kedua variable bebas lainnya yang berarti bahwa variabel Disiplin Kerja berpengaruh secara signifikan dan dominan terhadap Kinerja karyawan Bank Kaltimtara Cabang Balikpapan.
\end{abstract}

Kata Kunci: Disiplin, Gaya Kepemimpinan, Motivasi , Kinerja

\section{PENDAHULUAN}

Sumber daya manusia merupakan tokoh sentral dalam organisasi maupun perusahaan. Agar aktivitas manajemen berjalan dengan baik, perusahaan harus memiliki karyawan yang berpengetahuan dan berketrampilan tinggi serta usaha untuk mengelola perusahaan seoptimal mungkin sehingga kinerja karyawan meningkat.

Disiplin kerja, menurut Setiyawan dan Waridin (2010;95) sebagai keadaan ideal dalam mendukung pelaksanaan tugas sesuai aturan dalam rangka mendukung optimalisasi kerja. Setiyawan dan Waridi (2010;97), Salah satu syarat agar disiplin dapat ditumbuhkan dalam lingkungan kerja ialah, adanya pembagian kerja yang tuntas sampai kepada pegawai 
atau petugas yang paling bawah, sehingga setiap orang tahu dengan sadar apa tugasnya, bagaimana melakukannya, kapan pekerjaan dimulai dan selesai, seperti apa hasil kerja yang disyaratkan, dan kepada siapa mempertanggung jawabkan hasil pekerjaan itu. Untuk itu disiplin harus ditumbuh kembangkan agar tumbuh pula ketertiban dan evisiensi. Tanpa adanya disiplin yang baik, tidak akan dapat diwujudkan adanya sosok pemimpin atau karyawan ideal sebagaimana yang diharapkan oleh masyarakat dan perusahaan.

Regina (2010), Kinerja karyawan mempunyai beberapa faktor yang dapat mempengaruhi, salah satu faktor yang mempengaruhi kinerja karyawan adalah gaya kepemimpinan. Gaya kepemimpinan yang tepat akan menimbulkan motivasi seseorang untuk berprestasi. Sukses tidaknya karyawan dalam prestasi kerja dapat dipengaruhi oleh gaya kepemimpinan atasannya.

Gaya kepemimpinan menjadi faktor pertama dalam meningkatkan kinerja secara berkelanjutan. Pada proses ini pemimpin mempunyai peran yang besar dalam menentukan pelaksanaan organisasi suatu perusahaan. Seorang pemimpin dituntut untuk memberikan arahan yang jelas terhadap visi dan misi organisasi tersebut, dan mampu menjalankan organisasi dengan baik agar hasil yang didapatkan sesuai dengan tujuan yang ingin dicapai oleh perusahaan.

Selain dari faktor kepemimpinan, faktor lain adalah motivasi yang diberikan kepada pegawai. Motivasi dapat mendorong seorang karyawan dalam melaksanakan pekerjaan secara optimal sesuai dengan tujuan yang diinginkan oleh seorang pemimpin dalam menciptakan suasana kerja yang kondusif dalam perusahaan. Daya dorongan tersebut adalah motivasi.

Motivasi kerja memiliki pengaruh yang positif terhadap suatu organisasi dalam perusahaan, seperti yang telah diungkapkan oleh Hasibuan (2014), bahwa motivasi dapat meningkatkan produktivitas, kedisiplinan, dan dapat mempertinggi rasa tanggung jawab karyawan terhadap tugas-tugasnya.

Untuk menghadapi permasalahan yang dihadapi oleh PT. BPD Kaltim Kaltara dimasa yang akan datang, dengan semakin meningkatnya persaingan dalam perindustrian perbankan di Balikpapan, maka PT. BPD Kaltim Kaltara dituntut untuk mengalola sumber daya manusia yang handal, yaitu yang mampu bekerja lebih giat dalam rangka pencapaian target yang telah ditetapkan perusahaan. Berdasarkan uraian diatas, menjelaskan bahwa disiplin kerja, gaya kepemimpinan dan motivasi berhubungan dengan tingkat kinerja karyawan, maka tujuan dalam penelitian ini adalah untuk: 
1. Mengetahui secara simultan pengaruh disiplin kerja, gaya kepemimpinan, dan motivasi terhadap kinerja karyawan PT. Bank Pembangunan daerah Kalimantan Timur Dan Kalimantan Utara(Bpd Kaltim Kaltara) Cabang Balikpapan.

2. Mengetahui secara parsial pengaruh disiplin kerja, gaya kepemimpinan, dan motivasi terhadap kinerja karyawan PT. Bank Pembangunan daerah Kalimantan Timur Dan Kalimantan Utara (Bpd Kaltim Kaltara) Cabang Balikpapan.

3. Mengetahui diantara disiplin kerja, gaya kepemimpinan, dan motivasi yang berpengaruh terhadap kinerja karyawan PT. Bank Pembangunan daerah Kalimantan Timur Dan Kalimantan Utara(Bpd Kaltim Kaltara) Cabang Balikpapan.

\section{KERANGKA TEORI}

\section{Disiplin Kerja}

Hasibuan (2014:44) menyatakan bahwa: "Disiplin kerja adalah kesadaran dan kerelaan seseorang dalam menaati semua peraturan perusahaan dan norma-norma sosial yang berlaku." Menurut Rivai (2013:82) bahwa: "Disiplin kerja adalah suatu alat yang dipergunakan para manajer untuk berkomunikasi dengan karyawan agar mereka bersedia untuk mengubah suatu perilaku serta sebagai suatu upaya untuk meningkatkan kesadaran dan kesedian seorang dalam memenuhi segala peraturan perusahaan."

\section{Gaya Kepemimpinan}

Definisi gaya kepemimpinan menurut Thoha (2013:303) sebagai berikut: "Gaya kepemimpinan adalah suatu norma perilaku yang digunakan oleh seseorang pada saat orang tersebut mencoba mempengaruhi perilaku orang lain seperti yang ia lihat". Hasibuan (2014:170) adalah sebagai berikut: “Gaya kepemimpinan adalah suatu cara pemimpin untuk mempengaruhi bawahannya, agar mau bekerja sama dan bekerja secara produktif untuk mencapai tujuan organisasi".

\section{Motivasi}

Sutrisno (2015:109) mengemukakan motivasi adalah "faktor yang mendorong seseorang untuk melakukan suatu aktivitas tertentu, motivasi sering kali diartikan pula sebagai faktor pendorong perilaku seseorang”. Mangkunegara (2012:61) juga mengemukakan motivasi adalah "kondisi atau energi yang menggerakkan diri karyawan yang terarah atau tertuju untuk mencapai tujuan organisasi perusahaan”. Hasibuan (2014:141) motivasi berasal dari kata Latin movere yang berarti dorongan atau menggerakkan. Motivasi (motivation) dalam manajemen hanya ditujukan pada sumber daya manusia umumnya dan bawahan 
khususnya. Motivasi mempersoalkan bagaimana caranya mengarahkan daya dan potensi bawahan, agar mau bekerja sama secara produktif berhasil mencapai dan mewujudkan tujuan yang telah ditentukan.

\section{Kinerja}

Moeheriono (2012:95), "kinerja atau performance merupakan sebuah penggambaran mengenai tingkat pencapaian pelaksanaan suatu program kegiatan atau kebijakan dalam mewujudkan sasaran, tujuan, visi, dan misi organisasi yang dituangkan dalam suatu perencanaan strategis suatu organisasi”.

Sedangkan menurut Rivai (2013:604), “kinerja merupakan suatu istilah secara umum yang digunakan sebagian atau seluruh tindakan atau aktivitas dari suatu organisasi pada suatu periode dengan suatu referensi pada sejumlah standar seperti biaya masa lalu yang diproyeksikan dengan dasar efisiensi”.

\section{Kerangka Pemikiran}

Berdasarkan hubungan antar variabel diatas maka kerangka pemikiran penelitian ini adalah sebagai berikut:

Gambar 1.1

Kerangka Pemikiran

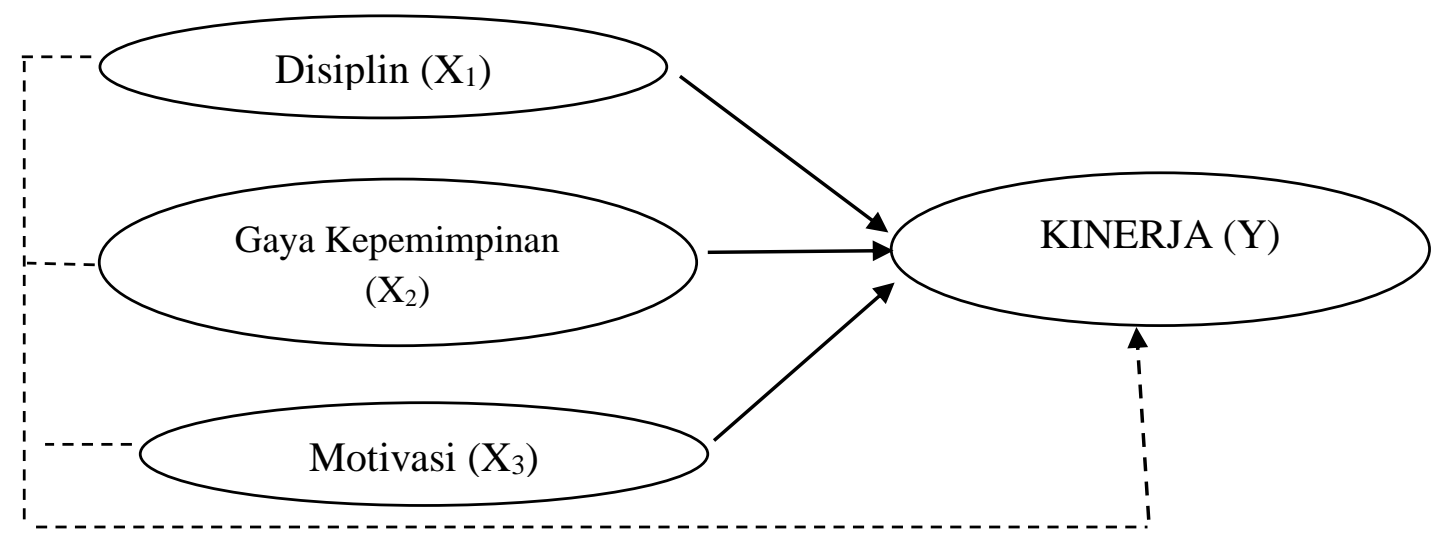

\section{Hipotesis Penelitian}

Adapun hipotesis dalam penelitian ini adalah sebagai berikut:

1. Bahwa Disiplin Kerja, Gaya Kepemimpinan, Dan Motivasi secara bersama-sama berpengaruh Terhadap Kinerja Karyawan PT Bank Pembangunan Daerah Kalimantan Timur dan Kalimantan Utara (BPD Kaltim Kaltara) Cabang Balikpapan. 
2. Bahwa Disiplin Kerja, Gaya Kepemimpinan, Dan Motivasi secara parsial berpengaruh Terhadap Kinerja Karyawan PT Bank Pembangunan Daerah Kalimantan Timur dan Kalimantan Utara (BPD Kaltim Kaltara) Cabang Balikpapan.

3. Bahwa Disiplin Kerja berpengaruh dominan terhadap Kinerja Karyawan PT Bank Pembangunan Daerah Kalimantan Timur dan Kalimantan Utara (BPD Kaltim Kaltara) Cabang Balikpapan.

\section{METODE PENELITIAN}

\section{Batasan Penelitian}

Objek penelitian dalam penulisan ini dilakukan pada Kantor PT Bank Pembangunan Daerah Kalimantan Timur dan Kalimantan Utara (BPD Kaltim Kaltara) Cabang Balikpapan. Penelitian ini hanya mengumpulkan data-data yang erat kaitannya dengan judul penelitian yang diajukan yaitu pengaruh disiplin kerja, gaya kepemimpinan, dan motivasi terhadap kinerja karyawan.

\section{Populasi dan Sampel}

Sugiyono (2016:80), populasi adalah "wilayah generlisasi yang terdiri atas obyek atau subyek yang mempunyai kualitas dan karakteristik tertentu yang ditetapkan oleh peneliti untuk dipelajari dan kemudian ditarik kesimpulannya". Dalam hal ini populasi Karyawan BPD Kaltim Kaltara Cabang Balikpapan adalah sejumlah 136 orang karyawan.

Sugiyono (2016:81), sampel adalah "bagian dari jumlah karakteristik yang dimiliki oleh populasi”. Teknik pengambilan sampel dalam penelitian ini menggunakan teknik sampling jenuh. Teknik sampling jenuh yaitu "teknik penentuan sampel bila semua anggota populasi digunakan sebagai sampel.

Suparmoko (2010:42) mengemukakan bahwa besarnya sampel dapat ditentukan dengan presentase tertentu misalnya 5\%,10\% atau 50\%. Dengan demikian, dari sejumlah populasi 136 orang diambil 50\% sebagai sampel yang telah ditetapkan diatas, maka jumlah sampel 68 orang sebagai representative populasi yang ada.

\section{Metode Pengumpulan Data}

Dalam rangka memperoleh data-data yang penulis butuhkan, maka di dalam penelitian ini penulis mengumpukan data-data dengan cara Studi Kepustakaan (Library Research), yaitu pengumpulan data yang dilakukan dengan mencari teori yang diperlukan 
melalui literatur-literatur serta penulisan-penulisan yang berhubungan dengan masalah yang akan dibahas. Studi Lapangan (Field Work Research) yaitu penelitian langsung dilaksanakan terhadap objek penelitian

\section{Definisi Operasional Variabel}

Disiplin kerja $\left(\mathrm{X}_{1}\right)$ adalah sikap kesadaran, kerelaan dan kesedian seseorang dalam mematuhi dan menaati peraturan dan norma-norma sosial yang berlaku di lingkungan sekitarnya. Robins (2005:182), adapun kriteria yang dipakai dalam disiplin kerja tersebut dapat dikelompokkan menjadi tiga indikator disipin kerja yaitu diantaranya:
a. Disiplin waktu
b. Disiplin Peraturan
c. Disiplin Tanggung Jawab

Gaya kepemimpinan $\left(\mathrm{X}_{2}\right)$ adalah suatu cara pemimpin untuk mempengaruhi bawahanya, agar mau bekerja sama dan bekerja secara produktif untuk mencapai tujuan organisasi. Hasibuan (2013:170) Beberapa Gaya Kepemimpinan yang dikemukakan oleh Hasibuan sebagai berikut:

a. Kepemimpinan Otoriter

b. Kepemimpinan Partisipatif

c. Kepemimpinan Delegatif

Motivasi adalah Keinginan yang muncul dari dalam seorang individu untuk bertindak dan melakukan sesuatu hal untuk mencapai tujuan tertentu. Indikator yang digunakan Maslow dalam Wukir (2013:120) Hierarki kebutuhan manusia adalah:
a. Kebutuhan Fisiologis
b. Kebutuhan Rasa Aman
c. Kebutuhan Sosial
d. Kebutuhan akan Penghargaan
e. Kebutuhan untuk Mengaktualisasikan Diri

kinerja merupakan hasil atau prestasi yang dicapai seseorang baik secara kualitas maupun kuantitas dalam melaksanakan pekerjaannya yang berhubungan dan berkontribusi bagi keberhasilan organisasi.

Suyadi Prawirosentono (2008: 27), kinerja dapat dinilai atau diukur dengan beberapa indikator yaitu:
a. Efektifitas 

b. Tanggung jawab
c. Disiplin
d. Inisiatif

\section{Metode Analisis}

\section{Uji Validitas dan Reliabilitas}

Uji Validitas menurut Ghozali (2011:45) digunakan untuk mengukur sah atau valid tidaknya suatu kuesioner. Suatu kuesioner dikatakan valid jika pernyataan pada kuesioner mampu untuk mengungkapkan sesuatu yang akan diukur oleh kuesioner tersebut. Suatu instrument dikatakan valid jika mempunyai validitas tinggi yaitu correlation $r$ hitung $>r$ tabel sebaiknya instrument yang kurang valid berarti memiliki validitas rendah dengan nilai correlation $r$ hitung.

Menurut Umar (2012:86) jika alat ukur telah dinyatakan valid, maka berikutnya alat ukur tersebut diuji reliabilitasnya. Setiap alat pengukur seharusnya memiliki kemampuan untuk memberikan hasil pengukuran yang konsisten. Untuk menentukan instrument itu reliabel atau tidak maka digunakan ketentuan: Jika alpa chronbach > 0,60 berarti variabel penelitian ini reliable. Jika alpa chronbach $<0,60$ berarti variabel penelitian ini tidak reliabel.

\section{Asumsi Klasik}

Pengujian asumsi klasik untuk menganalisis kelayakan model analisis regresi linear berganda dapat digunakan sebagai alat analisis dan pengujian dilakukan yaitu:

1. Uji Multikolineritas

2. Uji Heteoroskedastisitas

3. Uji Autokorelasi

\section{Analisis Regresi Linear Berganda}

Analisis ini digunakan untuk mengetahui seberapa besar pengaruh variabel bebas erhadap variabel terikatnya yaitu kinerja (Y).

Sugiyono (2016:6), adapun bentuk persamaan regresi yang digunakan pada penelitian ini menurut adalah:

$$
Y=\alpha+b_{1} X_{1}+b_{2} X_{2}+b_{3} X_{3}+e
$$

Dimana:

$$
\mathrm{Y} \quad=\text { Kinerja }
$$




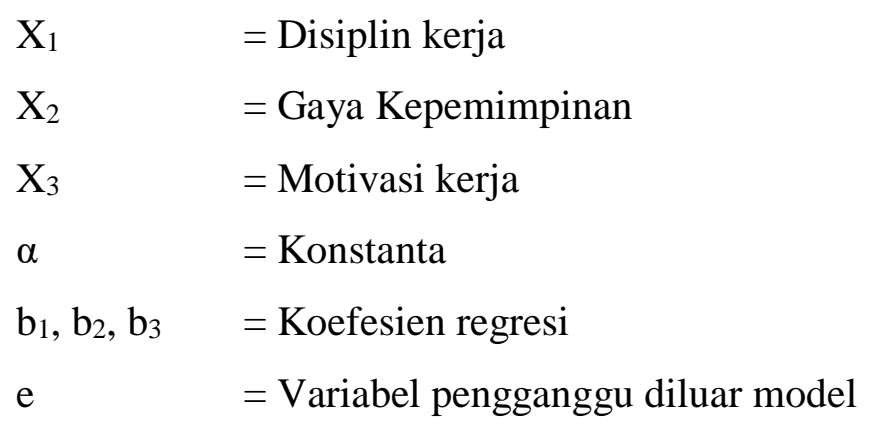

\section{Pengujian Hipotesis}

1. Uji F

Uji F digunakan untuk menguji tingkat signifikansi koefisien regresi variabel independen secara bersama-sama terhadap variabel dependen.

2. Uji T

Uji $\mathrm{T}$ digunakan untuk menguji pengaruh variabel bebas secara parsial atau masingmasing dengan kriteria pengujian.

\section{HASIL PENELITIAN DAN PEMBAHASAN}

\section{Hasil Penelitian}

\section{Hasil Uji Validitas}

Berdasarkan tabel 1 dapat diketahui besarnya koefisien korelasi (Pearson correlations) $\mathrm{r}_{\text {hitung }}$ dari setiap pertanyaan untuk masing-masing pada variabel Disiplin $\left(\mathrm{X}_{1}\right)$, Gaya kepemimpinan $\left(\mathrm{X}_{2}\right)$, Motivasi $\left(\mathrm{X}_{3}\right)$ dan variabel Kinerja $(\mathrm{Y})$ Karyawan Bankaltimtara > Pearson Correlation tabel hasil yang positif dan lebih besar dari $r_{\text {tabel }}$ yaitu 0,361. Dengan demikian pertanyaan yang ada pada instrumen penelitian dapat dinyatakan layak sebagai instrumen untuk menjadi data penelitian.

Tabel 1

Hasil Uji Validitas

\begin{tabular}{|c|c|c|c|c|}
\hline Variabel & Item & $\begin{array}{c}\text { Pearson } \\
\text { correlations }\end{array}$ & $\begin{array}{c}\mathrm{r} \text { tabel } \\
\mathrm{n}=30\end{array}$ & Keterangan \\
\hline \multirow{3}{*}{ Kinerja (Y) } & $\mathrm{Y} 1.1$ & 0,762 & 0.361 & Valid \\
& $\mathrm{Y} 1.2$ & 0,710 & 0.361 & Valid \\
& $\mathrm{Y} 1.3$ & 0,700 & 0.361 & Valid \\
& $\mathrm{Y} 1.4$ & 0,798 & 0.361 & Valid \\
\hline \multirow{3}{*}{ Disiplin $\left(\mathrm{X}_{1}\right)$} & $\mathrm{X} 1.1$ & 0,744 & 0.361 & Valid \\
& $\mathrm{X} 1.2$ & 0,719 & 0.361 & Valid \\
& $\mathrm{X} 1.3$ & 0,584 & 0.361 & Valid \\
\hline
\end{tabular}




\begin{tabular}{|l|l|l|l|l|}
\hline \multirow{3}{*}{ Gaya Kepemimpinan $\left(\mathrm{X}_{2}\right)$} & $\mathrm{X} 2.1$ & 0,717 & 0.361 & Valid \\
& $\mathrm{X} 2.2$ & 0,713 & 0.361 & Valid \\
& $\mathrm{X} 2.3$ & 0,729 & 0.361 & Valid \\
\hline & $\mathrm{X} 3.1$ & 0,671 & 0.361 & Valid \\
& $\mathrm{X} 3.2$ & 0,730 & 0.361 & Valid \\
& $\mathrm{X} 3.3$ & 0,687 & 0.361 & Valid \\
& $\mathrm{X} 3.4$ & 0,617 & 0.361 & Valid \\
& $\mathrm{X} 3.5$ & 0,642 & 0.361 & Valid \\
\hline
\end{tabular}

Sumber: Hasil analisis dengan menggunakan tabel dan SPSS 20

\section{Hasil Uji Reliabilitas}

Tabel 2

Hasil Pengujian Reliabilitas

\begin{tabular}{|l|c|c|c|}
\hline \multicolumn{1}{|c|}{ Variabel } & $\begin{array}{c}\text { Nilai } \text { r hitung } \\
\text { Alpha Crounbach }\end{array}$ & $\begin{array}{c}\text { Nilai r tabel } \\
\text { Alpha Crounbach }\end{array}$ & Keterangan \\
\hline Kinerja $(\mathrm{Y})$ & 0,796 & 0,60 & Reliabel \\
\hline Disiplin $\left(\mathrm{X}_{1}\right)$ & 0,752 & 0,60 & Reliabel \\
\hline Gaya Kepemimpinan $\left(\mathrm{X}_{2}\right)$ & 0,781 & 0,60 & Reliabel \\
\hline Motivasi $\left(\mathrm{X}_{3}\right)$ & 0,752 & 0,60 & Reliabel \\
\hline
\end{tabular}

Sumber : Hasil analisis menggunakan SPSS versi 20.

Hasil uji reliabilitas adalah semua pertanyaan untuk masing-masing variabel dalam penelitian ini dapat dinyatakan reliabel karena memiliki nilai Cronbach's Alpha > 0,60 maka dapat disimpulkan bahwa pertanyaan pada variabel Disiplin $\left(\mathrm{X}_{1}\right)$, Gaya Kepemimpinan $\left(\mathrm{X}_{2}\right)$, Motivasi $\left(\mathrm{X}_{3}\right)$ dan variabel Kinerja $(\mathrm{Y})$ Karyawan Bankaltimtara merupakan pertanyaan yang reliable dan andal, dapat diartikan bahwa secara menyeluruh kuesioner yang digunakan dalam penelitian ini.

\section{Hasil Uji Asumsi Klasik}

\section{Hasil Uji Multikolinearitas}

Multikolinieritas merupakan pengujian untuk mengetahui apakah variabel independen dalam persamaan regresi tersebut tidak saling berlinearitas atau saling mempunyai hubungan yang kuat (adanya hubungan regresi) antara variabel bebas. Hasil penulis cantumkan dalam tabel berikut ini:

Tabel 3

Hasil Uji Multikolinearitas 


\begin{tabular}{|l|c|c|c|}
\hline \multicolumn{1}{|c|}{ Variabel } & $\begin{array}{c}\text { Nilai } \\
\text { VIF }\end{array}$ & $\begin{array}{l}\text { Nilai } \\
\text { Kritis }\end{array}$ & Keterangan \\
\hline Disiplin $\left(\mathrm{X}_{1}\right)$. & 1,327 & 5 & \\
Gaya Kepemimpinan $\left(\mathrm{X}_{2}\right)$ & 1,526 & 5 & Tidak terjadi \\
Motivasi $\left(\mathrm{X}_{3}\right)$ & 1,619 & 5 & Multikolinearity \\
\hline
\end{tabular}

Sumber data : berdasarkan pengolahan dari hasil analisis dengan SPSS

Berdasarkan tabel 4.3 tersebut dapat diketahui bahwa variabel bebas yaitu variabel Disiplin $\left(\mathrm{X}_{1}\right)$ Nilai VIF $=1,327<5$, variabel Gaya Kepemimpinan $\left(\mathrm{X}_{2}\right)$ Nilai VIF $=1,526$ $<5$ variabel Motivasi $\left(\mathrm{X}_{3}\right)$ Nilai VIF $=1,619<5$ sehingga semua nilai VIF menunjukkan tidak terjadi Multikolinearity karena nilai VIF (Variance Inflation Factor) semua lebih kecil dari 5 pada matrik korelasi menunjukkan lebih besar dari nilai Kritisnya untuk $\alpha=$ 0,05 .

\section{Hasil Uji Autokorelasi}

Tabel 5

Autokorelasi

\begin{tabular}{|c|c|c|}
\hline $\begin{array}{c}\text { Interval Nilai Durbin } \\
\text { Watson tabel }\end{array}$ & $\begin{array}{c}\text { Nilai Durbin } \\
\text { Watson hitung }\end{array}$ & keterangan \\
\hline Kurang dari 1,65 & - & Terjadi Autokorelasi \\
\hline DW $1,65-1,69$ & - & Tidak ada kesimpulan \\
\hline $1,69<\mathrm{DW}<2,31$ & 2,275 & Tidak terjadi Autokorelasi \\
\hline $2,31<\mathrm{DW}<2,39$ & & Tidak ada kesimpulan \\
\hline DW $>2,39$ & - & terjadi Autokorelasi \\
\hline
\end{tabular}

Sumber data : berdasarkan pengolahan dari hasil analisis SPSS

Berdasarkan hasil analisis pada tabel 5 diperoleh nilai Durbin Watson hitung sebesar 2,275 nilai ini berada pada nilai interval Dubin Watson Tabel yaitu antara DW 1,69 sampai dengan 2,31 dinyatakan tidak terjadi autokorelasi pada Disiplin $\left(\mathrm{X}_{1}\right)$, Gaya Kepemimpinan $\left(\mathrm{X}_{2}\right)$, Motivasi $\left(\mathrm{X}_{3}\right)$.

\section{Hasil Analisis Regresi Linier Berganda}

Pembahasan yang digunakan dalam penelitian ini sesuai dengan data yang diambil dari hasil kuesioner responden PT Bankaltimtara cabang Balikpapan. Untuk penelitian ini dilakukan pengujian dengan menggunakan model analisis regresi berganda menggunakan program SPSS Versi 20. Hasil pengolahan data tersebut dengan menggunakan analisis regresi linear berganda. 
Tabel 6

Hasil Regresi linear berganda dan hasil uji secara Simultan

\begin{tabular}{|c|c|c|c|c|c|}
\hline \multicolumn{4}{|c|}{ Variabel } & \multicolumn{2}{|c|}{ Koefisien Regresi (b) } \\
\hline $\begin{array}{l}\text { Kinerja kary } \\
\text { Koefisien K } \\
\text { Disiplin (X } \\
\text { Gaya Kepem } \\
\text { Motivasi (X }\end{array}$ & $\begin{array}{l}\text { van }(\mathrm{Y}) \\
\text { istanta } \\
\text { mpinan }\left(\mathrm{X}_{2}\right)\end{array}$ & & & & $\begin{array}{r}446 \\
395 \\
342 \\
206 \\
\end{array}$ \\
\hline $\begin{array}{l}\text { Koefisien } \\
\text { Korelasi (R) }\end{array}$ & $\begin{array}{c}\text { Koefisien } \\
\text { Determinasi } \\
\text { (R Square) }\end{array}$ & Fhitung & Ftabel & Nilai Sig & Keterangan \\
\hline 0,805 & 0,647 & 39,144 & 2,76 & 0,000 & Signifikan \\
\hline
\end{tabular}

Sumber : diolah menggunakan program SPSS

Tabel 7

Hasil Koefisien Regresi, Korelasi dan Uji t

\begin{tabular}{|l|c|c|c|c|c|}
\hline \multicolumn{1}{|c|}{ Variabel } & $\begin{array}{c}\text { Koefisien } \\
\text { Korelasi } \\
\text { Parsial (r) }\end{array}$ & $\mathrm{t}_{\text {hitung }}$ & $\mathrm{t}_{\text {tabel }}$ & Sig & Keterangan \\
\hline Disiplin $\left(\mathrm{X}_{1}\right)$ & 0,512 & 4,764 & 2,021 & 0,000 & Signifikan \\
Gaya Kepemimpinan $\left(\mathrm{X}_{2}\right)$ & 0,434 & 3,852 & 2,021 & 0,000 & Signifikan \\
Motivasi $\left(\mathrm{X}_{3}\right)$ & 0,298 & 2,502 & 2,021 & 0,019 & Signifikan \\
\hline
\end{tabular}

Sumber : diolah menggunakan program SPSS

Berdasarkan hasil analisis diperoleh hasil persamaan regresi linier berganda untuk hasil penelitian pengaruh variabel Disiplin $\left(\mathrm{X}_{1}\right)$, Gaya Kepemimpinan $\left(\mathrm{X}_{2}\right)$, Motivasi $\left(\mathrm{X}_{3}\right)$ berpengaruh terhadap Kinerja (Y) karyawan Bank Kaltimtara Cabang Balikpapan yaitu diperoleh persamaan Regresi linear berganda:

$$
Y=0,446+0,395 X_{1}+0,342 X_{2}+0,206 X_{3}
$$

Hasil persamaan regresi berganda tersebut dapat dijelaskan pengertian berdasarkan analisis statistik sebagai berikut:

Nilai koefisien konstanta sebesar bo $=0,446$ menunjukan pada saat variabel Disiplin $\left(\mathrm{X}_{1}\right)$, Gaya Kepemimpinan $\left(\mathrm{X}_{2}\right)$, Motivasi $\left(\mathrm{X}_{3}\right)$ menunjukkan nilai konstan atau nol maka Kinerja (Y) karyawan Bank Kaltimtara Cabang Balikpapan sebesar 0,446 jika disetarakan dalam persentase maka didapat $44,6 \%$. 
Adapun nilai-nilai koefisien regresi untuk tiap-tiap variabel dapat dijelaskan pengertian berdasarkan analisis statistic sebagai berikut:

1. Hubungan antara variabel Disiplin $\left(\mathrm{X}_{1}\right)$ terhadap variabel Kinerja $(\mathrm{Y})$ pada karyawan Bank Kaltimtara Cabang Balikpapan dengan Nilai Koefisien Regresi $b_{1}=0,395$ yang menunjukkan setiap kenaikan variabel Disiplin $\left(\mathrm{X}_{1}\right)$ sebesar satu satuan akan mempengaruhi terhadap Kinerja (Y) karyawan Bank Kaltimtara Cabang Balikpapan dengan nilai Koefisien regresi $\mathrm{b}_{1}$ sebesar 0,395 dengan asumsi Gaya Kepemimpinan $\left(\mathrm{X}_{2}\right)$ , Motivasi $\left(\mathrm{X}_{3}\right)$ nilainya konstan.

2. Hubungan antara variabel Gaya Kepemimpinan $\left(\mathrm{X}_{2}\right)$ terhadap variabel Kinerja $(\mathrm{Y})$ pada karyawan Bank Kaltimtara Cabang Balikpapan dengan Nilai Koefisien Regresi $b_{2}=$ 0,342 yang menunjukkan setiap kenaikan variabel Gaya Kepemimpinan $\left(\mathrm{X}_{2}\right)$ sebesar satu satuan akan mempengaruhi terhadap Kinerja (Y) karyawan Bank Kaltimtara Cabang Balikpapan dengan nilai Koefisien regresi $b_{2}$ sebesar 0,342 dengan asumsi Disiplin $\left(\mathrm{X}_{1}\right)$, Motivasi $\left(\mathrm{X}_{3}\right)$ nilainya konstan.

3. Hubungan antara variabel Motivasi $\left(\mathrm{X}_{3}\right)$ terhadap variabel Kinerja $(\mathrm{Y})$ pada karyawan Bank Kaltimtara Cabang Balikpapan dengan Nilai Koefisien Regresi $b_{3}=0,206$ yang menunjukkan setiap kenaikan variabel Motivasi $\left(\mathrm{X}_{3}\right)$ sebesar satu satuan akan mempengaruhi terhadap Kinerja (Y) karyawan Bank Kaltimtara Cabang Balikpapan dengan nilai Koefisien regresi $b_{3}$ sebesar 0,206 dengan asumsi Disiplin ( $\left.\mathrm{X}_{1}\right)$, Gaya Kepemimpinan $\left(\mathrm{X}_{2}\right)$, nilainya konstan.

\section{Pengujian Hipotesis}

\section{Hasil Uji Hipotesis F}

Berdasarkan hasil analisis yang dikemukakan pada tabel 4.10 diperoleh hasil pengujian secara simultan dengan menggunakan analisis Fisher test yaitu diperoleh nilai Fhitung sebesar sedangkan $\mathrm{F}$ tabel derajat keyakinan $95 \%(\alpha=0,05)$ dan n-k-1 = $68-3-1=$ 64 dan $\mathrm{k}-1=4-1=3$ dan maka diketahui F-hitung = 39,144 > F-tabel = 2,76 pada sig sebesar $0,000<0,05$ berarti secara simultan terbukti bahwa variabel Disiplin $\left(\mathrm{X}_{1}\right)$, Gaya Kepemimpinan $\left(\mathrm{X}_{2}\right)$, Motivasi $\left(\mathrm{X}_{3}\right)$ berpengaruh terhadap Kinerja (Y) karyawan Bank Kaltimtara Cabang Balikpapan.

Nilai koefisien korelasi $(R)=805$ nilai mendekati angka 1 berarti terdapat adanya hubungan yang kuat antara variabel Disiplin $\left(\mathrm{X}_{1}\right)$, Gaya Kepemimpinan $\left(\mathrm{X}_{2}\right)$, Motivasi $\left(\mathrm{X}_{3}\right)$ berpengaruh terhadap Kinerja (Y) karyawan Bank Kaltimtara Cabang Balikpapan. 
Berdasarkan hasil Koefisien determinasi $\left(\mathrm{R}^{2}\right)=0,647$ nilai ini menunjukkan bahwa kontribusi variabel Disiplin $\left(\mathrm{X}_{1}\right)$, Gaya Kepemimpinan $\left(\mathrm{X}_{2}\right)$, Motivasi $\left(\mathrm{X}_{3}\right)$ berpengaruh terhadap Kinerja (Y) karyawan Bank Kaltimtara Cabang Balikpapan sebesar 64,7\% dan sisanya sebesar 35,3\% merupakan kontribusi variabel lain yang tidak masuk analisis penelitian ini.

\section{Hasil Uji t (Uji Hipotesis Parsial)}

Hasil perhitungan pada tabel 7 menunjukkan bahwa:

1. Secara parsial Pengaruh Disiplin $\left(\mathrm{X}_{1}\right)$ terhadap Kinerja karyawan Bank Kaltimtara Cabang Balikpapan dengan hasil secara parsial dengan pengujian signifikansi $5 \%$ dua sisi dengan hasil $t_{\text {hitung }}=4,761>\mathrm{t}_{\text {tabel }}=2,021$ pada sig $0,000<0,05$ dan nilai koefisien korelasi parsialnya (r) sebesar 0,512 yang berarti bahwa variabel Disiplin ( $\left.\mathrm{X}_{1}\right)$ berpengaruh secara signifikan terhadap karyawan Bank Kaltimtara Cabang Balikpapan.

2. Secara parsial Pengaruh Gaya Kepemimpinan $\left(\mathrm{X}_{2}\right)$ terhadap terhadap Kinerja karyawan Bank Kaltimtara Cabang Balikpapan dengan hasil secara parsial dengan pengujian signifikansi $5 \%$ dengan dua sisi diperoleh $t_{\text {hitung }}=3,852>t_{\text {tabel }}=2,021$ pada sig $0,000<$ 0,05 dan nilai koefisien korelasi parsialnya ( $\mathrm{R}$ ) sebesar 0,434 yang berarti bahwa variabel Gaya Kepemimpinan $\left(\mathrm{X}_{2}\right)$ berpengaruh secara signifikan terhadap Kinerja karyawan Bank Kaltimtara Cabang Balikpapan.

3. Secara parsial diperoleh Pengaruh Motivasi $\left(\mathrm{X}_{3}\right)$ terhadap Kinerja karyawan Bank Kaltimtara Cabang Balikpapan. Dengan hasil secara parsial dengan pengujian signifikansi $5 \%$ dua sisi diperoleh $t_{\text {hitung }}=2,502>t_{\text {tabel }}=2,021$ pada sig $0,015<0,05$ dan nilai koefisien korelasi parsialnya ${ }^{\circledR}$ sebesar 0,296 yang berarti bahwa variabel Motivasi $\left(\mathrm{X}_{3}\right)$ berpengaruh secara signifikan terhadap Kinerja karyawan Bank Kaltimtara Cabang Balikpapan.

4. Secara parsial diperoleh variabel Disiplin Kerja $\left(X_{1}\right)$ berpengaruh dominan Terhadap Kinerja Karyawan (Y) PT Bank Pembangunan Daerah Kalimantan Timur dan Kalimantan Utara (BPD Kaltim Kaltara) Cabang Balikpapan dengan hasil secara parsial dengan pengujian signifikansi 5\% dengan dua sisi diperoleh diperoleh $t_{\text {hitung }}=4,765>t_{\text {tabel }}=$ 2,021 pada sig $0,000<0,05$ dan nilai koefisien korelasi parsialnya ${ }^{\circledR}$ sebesar 0,512 nilai ini lebih besar dari hasil pengujian secara parsial pada kedua variable bebas lainnya yang berarti bahwa variabel Disiplin Kerja $\left(\mathrm{X}_{1}\right)$ berpengaruh secara signifikan dan dominan terhadap Kinerja karyawan Bank Kaltimtara Cabang Balikpapan. 


\section{PEMBAHASAN}

\section{Pengaruh Disiplin, Gaya Kepemimpinan dan Motivasi Terhadap Kinerja Karyawan}

Berdasarkan hasil analisis variabel Disiplin, Gaya Kepemimpinan dan motivasi mempunyai pengaruh terhadap variabel Kinerja karyawan PT Bank BPD Kaltimtara Cabang Balikpapan sangat bergantung terhadap keberhasilan dari pelaksanaan Disiplin yaitu pelaksanaan pekerjaan dilakukan sesuai dengan ketentuan yang berlaku dan mematuhi peraturan yang sudah ditentukan, gaya kepemimpinan yang merupakan pendukung dalam mengarahkan karyawan dan motivasi yang berupa kesediaan serta kemauan karyawan bekerja untuk mencapai hasil secara maksimal.

Hasil ini sejalan dengan penelitian terdahulu yang dilakukan oleh Aurelia Potu, penelitian yang dilakukan oleh Christian Katiandagho, Silvya L. Mand, Lisbeth Mananeke, penelitian yang dilakukan oleh Patricia M. Sahangggamu, Silvya L. Mandey ada dua persamaan yang sama namun satu yang berbeda yaitu patricia menggunakan pelatihan kerja sedangkan penelitian ini menggunakan Gaya Kepemimpinan dua variabel lain sama digunakan. Terhadap penelitian Bagus Ikhsan Bagaskara, Edy Rahardja ada perbedaaan satu variabel bebas yaitu Bagus menggunakan variabel Kepuasan kerja dan pada penelitian ini Gaya Kepemimpinan, dua variabel bebas lainnya sama. Terhadap penelitian Galan Kusuma, Edy Rahardja ada perbedaan penggunaan variabel bebas yaitu Galan menggunakan budaya organisasi sebagai variabel bebas dan pada penelitian ini Disiplin kerja sedang dua variabel bebas lainnya sama.

\section{Pengaruh Disiplin Terhadap Kinerja Karyawan}

Berdasarkan hasil analisis disiplin kerja merupakan hal yang dapat mempengaruhi kinerja karyawan maka kewajiban segenap unsur organisasi untuk mematuhi serta mentaati aturan, norma, etika yang telah ditetapkan untuk berlaku dalam organisasi, hal inilah yang patut diperhatikan oleh segenap unsur organisasi sebab bila terjadi pelanggaran maka akan menghadapi keonsekuensi sanksi sesuai ketentuan yang berlaku.

Hasil pengujian ini sejalan dengan penelitian Christian Katiandagho, Silvya L. Mand, Lisbeth Mananeke, penelitian Patricia M. Sahangggamu, Silvya L. Mandey, penelitian Bagus Ikhsan Bagaskara.

\section{Pengaruh Gaya Kepemimpinan Terhadap Kinerja Karyawan}


Dengan hasil Gaya Kepemimpinan yang berpengaruh signifikan terhadap Kinerja karyawan pada PT Bank BPD Kaltimtara Cabang Balikpapan maka dapat diartikan bahwa karyawan PT Bank BPD Kaltimtara terpengaruh dengan bagaimana seorang pimpinan mengatur mereka dalam pelaksanaaan pekerjaan dalam hal ini karyawan masih sangat bergantung kepada cara dan gaya pimpinannya sehingga kinerja karyawan dapat dicapai dengan maksimal dengan kemampuan pimpinan dalam mengendalikan, mengarahkan dan memberi petunjuk kepada karyawan dengan ketiga gaya dapat diterapkan oleh pimpinan. Hal ini karena karakteristik perusahaan yang mengajar target dengan segera pimpinan perlu bersifat otokratis, dan pada kondisi normal pimpinan dapat menerapkan demokratis dan pada saat target sudah dapat dicapai pimpinan dapat bersikap bebas.

Penelitian ini sejalan dengan penelitian dari penelitian Aurelia Potu, penelitian Christian Katiandagho, Silvya L. Mand, Lisbeth Mananeke, penelitian Galan Kusuma, Edy Rahardja.

\section{Pengaruh Motivasi Terhadap Kinerja Karyawan}

Motivasi merupakan hal yang dapat mempengaruhi kinerja karyawan hal ini menunjukkan bahwa pegawai di lingkup kerja pada Bank BPD Kaltimtara Cabang Balikpapan dimana mempunyai suatu semangat atau dorongan untuk melaksanakan pekerjaan secara maksimal. Dengan harapan adanya tambahan penghasilan diluar gaji baik berupa insentif, honor dan lainnya yang dapat untuk keperluan diluar kebutuhan pokok (Basic need). Penelitian yang mendukung adalah penelitian Aurelia Potu, penelitian Christian Katiandagho, Silvya L. Mand, Lisbeth Mananeke, penelitian Patricia M. Sahangggamu, Silvya L. Mandey, penelitian Bagus Ikhsan Bagaskara penelitian Galan Kusuma, Edy Rahardja.

\section{KESIMPULAN DAN SARAN}

\section{Kesimpulan}

1. Bahwa Disiplin Kerja $\left(X_{1}\right)$, Gaya Kepemimpinan $\left(X_{2}\right)$, Dan Motivasi $\left(X_{3}\right)$ secara bersama-sama berpengaruh Terhadap Kinerja Karyawan (Y) PT Bank Pembangunan

Daerah Kalimantan Timur dan Kalimantan Utara (BPD Kaltim Kaltara) Cabang Balikpapan.

2. Bahwa Disiplin Kerja $\left(\mathrm{X}_{1}\right)$ berpengaruh Terhadap Kinerja Karyawan (Y) PT Bank Pembangunan Daerah Kalimantan Timur dan Kalimantan Utara (BPD Kaltim Kaltara) Cabang Balikpapan. 
3. Bahwa Gaya Kepemimpinan $\left(\mathrm{X}_{2}\right)$, berpengaruh Terhadap Kinerja Karyawan (Y) PT Bank Pembangunan Daerah Kalimantan Timur dan Kalimantan Utara (BPD Kaltim Kaltara) Cabang Balikpapan.

4. Bahwa Motivasi $\left(\mathrm{X}_{3}\right)$ berpengaruh Terhadap Kinerja Karyawan (Y) PT Bank Pembangunan Daerah Kalimantan Timur dan Kalimantan Utara (BPD Kaltim Kaltara) Cabang Balikpapan.

5. Bahwa Disiplin Kerja $\left(\mathrm{X}_{1}\right)$ berpengaruh dominan Terhadap Kinerja Karyawan (Y) PT Bank Pembangunan Daerah Kalimantan Timur dan Kalimantan Utara (BPD Kaltim Kaltara) Cabang Balikpapan dengan hasil secara parsial mempunyai nilai yang lebih besar daripada hasil pengujian secara parsial pada kedua variabel bebas lainnya.

\section{Saran-Saran}

1. Disiplin karyawan berpengaruh terhadap Kinerja Karyawan karyawan Bank Kaltimtara Cabang Balikpapan maka berarti bahwa Bank Kaltimtara Cabang Balikpapan harus memperhatikan serta perlu menanamkan sikap disiplin pada karyawan dalam melakukan pekerjaannya oleh karena karyawan Bank merupakan public figure sehingga masyarakat selaku nasabah merasakan langsung kinerja karyawan yang ditunjukkan dengan disiplin karyawan .

2. Gaya Kepemimpinan berpengaruh terhadap Kinerja karyawan Bank Kaltimtara Cabang Balikpapan,maka hendaknya pimpinan senantiasa dapat bersikap sebagai pimpinan yang memiliki sikap tegas, serta menguasai tentang perbankan sehingga mampu memberikan arahan, petunjuk sera tuntunan kepada karyawan untuk melakukan pekerjaan secara benar efisien dan efektif sehingga kinerja dapat dicapai secara maksimum.

3. Motivasi berpengaruh terhadap Kinerja karyawan Bank Kaltimtara Cabang Balikpapan hal ini hendaknya pimpinan bank menyadari bahwa karyawan memerlukan suatu kepastian baik dari sudut penghasilannya layak sehingga bagi karyawan yang motifnya bekerja untuk memperoleh penghasilan untuk memenuhi kebutuhannya disamping itu karyawan yang memiliki motivasi bekerja untuk berkarier maka pimpinan perlu memperhatikan pengembangannya.

\section{DAFTAR PUSTAKA}

Aditya Reza, Regina, 2010, Pengaruh Gaya Kepemimpinan, Motivasi, dan Disiplin Kerja terhadap Kinerja Karyawan PT. Sinar Santosa Perkasa Banjarnegara. Universitas Diponegoro, Semarang. 
A.A Anwar Prabu Mangkunegara (2012). Manajemen Sumber Daya Manusia. Bandung: PT. Remaja Rosdakarya.

Ardana, I Komang dkk. 2012. Manajemen Sumber Daya Manusia. Yogyakarta: Graha ilmu.

Dessler, Gary. 2015. Manajemen Sumber Daya Manusia. Jakarta: Salemba Empat.

Danim, Sudarwan. 2011. Motivasi Kepemimpinan dan Motivasi Kelompok. Jakarta: PT. Rineka Cipta.

Fahmi, Irfan.2016. Pengantar Manajemen Sumber Daya Manusia Konsep dan Kinerja. Jakarta:Mitra Wacana Media

Hasibuan, Malayu. S.P 2014. Manajemen Sumber Daya Manusia (EdisiRevisi). BumiAksara. Jakarta

Handoko, T. Hani. 2012.Manajemen Personalia dan Sumber Daya Manusia. Yogyakarta:BPFE.

Husein Umar. 2013. Metode Penelitian untuk Skripsi dan Tesis. Jakarta: Rajawali

Irma Nilasari dan Sri Wiludjeng, 2006. Pengantar Bisnis. Edisi Pertama. Yogyakarta: Graha Ilmu.

Kartono Kartini Dr. 2010. Pemimpin dan Kepemimpinan. Jakarta: PT. Raja Grafindo Perkasa.

Mathis, Robert L. dan John H. Jackson. (2012). Manajemen Sumber Daya Manusia, Edisi Pertama Salemba Empat, Jakarta

Mangkunegara, Anwar Prabu. 2006. Evaluasi Kinerja SDM. Bandung : Refika Aditama.

Miftah Thoha. 2003, Kepemimpinan Dalam Manajemen Jakarta : PT. Raja Grafindo Persada.

Mahmudi (2010), Manajemen Kinerja Sektor Publik, Edisi Kedua, UPP STIM YKPN, Yogyakarta.

Mulyadi. 2007. Sistem Perencanaan dan Pengendalian Manajemen. Jakarta: Salemba Empat.

Pasolong, Harbani. 2010.Teori Administrasi Publik. Bandung: Alfabeta.

Ranupandojo, Heidjachman dan Suad Husnan, 2004. Manajemen Personalia. Cetakan Kesepuluh. Yogyakarta.

Rivai, Veithzal dan Ella Djauhari Sagala, 2013, Manajemen Sumbert Daya Manusia Untuk Perusahaan, Rajawali Pers, Jakarta.

Robbins SP, dan Judge. 2008. Perilaku Organisasi Buku 2, Jakarta : Salemba Empat Halaman 256.

Sedarmayanti. (2014). Sumber Daya Manusia dan Produktivitas Kerja. Jakarta: Mandar Maju.

Siagian,Sondang.P.2008. Manajemen Sumber Daya Manusia. Jakarta: Bumi Aksara.

Sunyoto, Danang. 2015. Manajemen dan Pengembangan Sumber Daya Manusia (Cetakan Pertama). Yogyakarta: CAPS (Center for Academic Publishing Service).

Sutrisno, Edy. 2015. Manajemen Sumber Daya Manusia (Cetakan ke tujuh). Jakarta: Kencana Prenada Media Group.

Suyadi, Prawirosentono. 2008. Manajemen Sumber Daya Manusia Kebijakan Kinerja Karyawan. Yogyakarta: BPFE.

Sugiyono. (2016). Metode Penelitian Kuantitatif Kualitataif dan Kombinasi (Mixed Methods). Bandung: Alfabeta.

VeithzalRivai\& Dedi Mulyadi, (2012), Kepemimpinan dan Perilaku Organisasi, Jakarta, Raja Grafindo Persada.

Veithzal Rivai, 2013, Manajemen Sumber Daya Manusia Untuk Perusahaan Dari Teori Ke Praktek, Rajagrafindo persada, Bandung.

Wukir. 2013. Manajemen Sumber Daya Manusia dalam Organisasi Sekolah. Yogyakarta: Multi Presindo. 
Wirawan. 2009. Evaluasi Kinerja Sumber Daya Manusia : Teori Aplikasi dan Penelitian. Jakarta: Salemba Empat.

Winardi. 2011. Kepemimpinan dalam Manajemen, PT. Rineka Cipta. Jakarta. 